\title{
In the North, the East and West meet. Festschrift for Jens Petter Nielsen
}

\author{
Kari Aga Myklebost \& Stian Bones (red.) \\ Stamsund: Orkana Akademisk 2019 \\ 408 sidor. ISBN 9788281043442
}

Recenserad av Ingmar Oldberg (associerad forskare, Utrikespolitiska institutet, Stockholm, ingmar.oldberg@gmail.com)

Den här boken omfattar 26 artiklar av Jens Petter Nielsens kollegor och vänner till minne av hans 70-årsdag, skrivna på engelska, nynorsk, bokmål och ryska med förnämligt bildmaterial, fotnoter och komplett bibliografi.

Enligt förordet eftersträvas balans mellan nordiska och ryska författare och mellan könen. Bokens titel föranleds av att i Arktis kommer Ryssland och Norge/Europa varandra närmast, och att Nielsen ägnat större delen av sitt yrkesliv åt att studera hur denna närhet påverkat såväl ländernas hotföreställningar och säkerhetspolitik som möten och samverkan mellan folken.

Boken inleds som sig bör med en biografisk essä av redaktörerna om jubilaren. Nielsen växte upp i Alta i Finnmark och studerade ryska och statskunskap i Oslo. Efter militärtjänst med mera ryska och en tid vid norska ambassaden i Moskva tog han kandidatexamen i historia i Oslo och började undervisa om revolutionen 1917 och Sovjetunionen. 1984 återvände han till Alta med ett uppdrag att skriva stadens historia, vilket inkluderade säkerhetspolitik, förhållandet till Ryssland och Pomorhandeln. Samtidigt med Gorbatjovs perestrojka, glasnost och slutet på det kalla kriget utnämndes Nielsen till professor i historia vid universitetet i Tromsö 1990 och till professor i High North Studies fyra år senare. Där skrev han en rad artiklar om rysk-norsk historia och blev drivande i att upprätta kontakter med ryska universitet, först Pomor-universitetet i Archangelsk.

Han har gett ut flera volymer med ryska forskare som också översatts, till exempel Den menskelige dimensionen i nordområdene (1994), Frykt og forventning. Russland og Norge $i$ det 20. Arhundre (1996), och Russland kommer ncermere (2014). Han fick ta emot Gorbatjov när denne blev hedersdoktor i Tromsö 1998, och blev själv hedersdoktor i Archangelsk samma år. Han tillbringade en sommar i Barentsburg, blev gästprofessor i Murmansk och fick åka rysk isbrytare till Jenisej och till Nordpolen (där OS-facklan tändes 2013). Redaktörerna betonar Nielsens internationella 
perspektiv och samarbete, som enligt honom själv leder till ömsesidig anpassning kanske dock inte numera.

Bokens följande artiklar grupperas efter Nielsens intresseområden. Angående ryska revolutionen analyserar Åsmund Egge judarnas roll och finner bland annat att de var fler inom mensjevikpartiet än bland bolsjevikerna. Archangelsk-kollegan Vladislav I. Goldin gillar att myndigheterna sedan 100-årsminnet talar om "den Stora ryska (rossijskaja) revolutionen» som lika viktig som den franska eller kinesiska (som inte brukar kallas 'stora') men ondgör sig över den "nya konservativa mytologin» och "hovhistoriker», som talar om kaos och röd terror. Han menar att folket genom sina "massorgan» ville ha social rättvisa och ett nytt samhälle, och framhåller att opinionsundersökningar 2017 visar att de flesta var positiva till revolutionen och dess resultat men inte ville ha en ny. (Den engelska artikelsammanfattningen nämner inte Goldins kontroversiella ställningstagande.)

Pål Kolstø betonar att revolutionsjubileet 2017 var obekvämt för Putins regim, men det ignorerades inte utan hänvisades till historikerna, vars sällskap organiserade en mängd arrangemang. Myndigheterna oroade sig för splittring och uppror, vilket stödet för revolutionen bekräftade, och manade till försoning och enhet. Putin avlägsnar sig från det sovjetiska arvet och bygger en ny ideologi byggd på traditionella värden, konservatism, religiös ortodoxi och det tsaristiska arvet.

I sin artikel om rysk historiekultur menar svensken Klas-Göran Karlsson i Nielsens efterföljd att krig har efterträtt revolution som främsta tema och kontinuitet och stabilitet ersatt förändring. Segern 1945 kan underbygga nuvarande kriget mot det väststödda Ukraina och motivera militarisering och ökad samhällskontroll. Putin har blivit alltmer engagerad i historia och strävat efter konsensus, vilket dock även bidragit till ökad splittring. Karlsson urskiljer olika tidslager i rysk historiesyn, varvid det djupaste, förknippat med Kiev-staten, underblåser konflikten med Ukraina, något som manifesterats med nya monument.

På temat norsk-ryska relationer hävdar Roald Berg att Norge under 1800-talet hyste konstant misstro mot Storbritannien men bara i växlande grad mot Ryssland. Han medger att det fanns en liberal ekonomisk intressegemenskap med britterna, men pekar på misstro mot imperialismen, fiskekonflikter, Bodö-saken med engelska smugglare och en antibrittisk dikt av Ibsen. Beträffande Ryssland anser Berg i Nielsens efterföljd att det aldrig utgjorde ett hot mot Norge och att russofobin och talet om ryska expansionsplaner i Nordnorge underblåstes av norska militärer och den brittiske konsuln och affärsmannen J.C. Crowe. Han framhåller värdet av Pomorhandeln med Nordnorge men bortser från den ryska autokratin och imperialismen, som ledde till interventioner i Ungern och Polen och flera krig mot Turkiet, liksom från att den svenska utrikesledningen (som skötte norsk utrikespolitik) blivit alltmer antirysk efter kung Karl XVI Johan. Under Krimkriget stödde Oscar I västmakterna och utverkade en säkerhetsgaranti för Finnmark. Dessförinnan hade Ryssland rest krav på fiskerättigheter i Varangerfjorden och spärrat gränsen för norska samers renbete. 
Bokens norsk-ryska tema förs sedan vidare av försvarsforskaren Sven G. Holtsmark, som tydligt skildrar avbrottet av de diplomatiska relationerna efter bolsjevikkuppen 1917 fram till deras återupptagande 1921, samt Aleksej Komarov vid Institutet för världshistoria i Moskva, som utifrån utrikesministeriets arkiv detaljerat belyser vad han kallar återupprättandet av den sovjetisk-norska gränsen efter andra världskriget, då Finland förlorade Petsamo-området. De ryska propåerna om Svalbard nämns inte.

Den mest aktuella artikeln i samlingen är av Arktis-experten Willy Østreng, som polemiserar mot talet om en kapplöpning om arktiska havsresurser. Enligt honom finns det inga fria resurser och inga strider, eftersom alla kuststater, även Ryssland, respekterar FN:s havsrättskonvention (UNCLOS) med dess organ och samarbetar i Arktis. Han nämner dock att det finns överlappande krav vid Nordpolen, att Nordost- och Nordvästpassagernas status är omstridd och att icke-arktiska stater borde ha intresse av att följa regelverket. Frågan är också om Ryssland går att lita på sedan det bröt mot internationell rätt i fråga om Georgien 2008 och Ukraina 2014 och nu formellt gör sina egna lagar överordnade.

Flera artiklar belyser speciella aspekter av relationerna med Ryssland, alltifrån Tatiana N. Dzjaksons analys av äktenskap och allianser i Norge under 1000-talet på grundval av gammalnorska och isländska sagor och Vladimir A. Karelins belysning av affärsmannen Jonas Lieds lovande verksamhet i Sibirien på 1910-talet, som avbröts av revolutionen, till Hallvard Tjelmelands framställning om vänortssamarbetet Tromsö-Murmansk som började redan på 1960-talet och växte från 1980-talet. Boken rymmer vidare några kapitel om historier i Finnmark, varvid jag finner ett om norrmännen som flydde till SSSR 1940 och utbildades till partisaner i Finnmark mest intressant. Rysk litteratur, konst och film glöms inte heller bort.

Boken avslutas med entusiastiska ryska vittnesmål om det vetenskapliga samarbetet med bland andra Nielsen. Det sista kapitlet om en gemensam utställning 2004 som Nielsen låg bakom, med syfte att övervinna stereotyper, måste dock konstatera att detta var mycket svårt. Rysslands politiska utveckling sedan dess torde ha giort det än svårare. Sammanfattningsvis kan sägas att denna bok håller hög kvalitet och kan tillfredsställa många läsares intressen. 